DOI: $10.17148 /$ IARJSET.2021.8919

\title{
Study on Impact of Covid-19 Pandemic on Middle- Class Income with reference in Mumbai and Navi Mumbai City
}

\author{
Lata S. Lokhande ${ }^{1}$ and Akshita S. Lokhande ${ }^{2}$ \\ ${ }^{1}$ Assistant Professor in SIES (Nerul) College of Arts, Science and Commerce, Navi Mumbai, Maharashtra, India \\ ${ }^{2}$ Student Higher Secondary Section (Std 12) SIES College of Commerce and Economics, \\ Sion (East), Maharashtra, India.
}

\begin{abstract}
During Covid-19 pandemic, government of India took major steps to control the spread of disease. Out of it, the major step was lockdown. Due to lockdown many industries are compel to stop their operations, which has severe impact on the businesses. Some businesses are even made losses during pandemic. All these have serious impact on the payment of wages and salaries. Many organizations couldn't afford to make payment to workers and staff. To minimize the cost operation, organizations started curtaining the wages and salaries of their employees. Even in some organizations started retrenchment of workforce. Due to pandemic situation many people have lost their jobs and some got less pay scale. The objective of this paper is to study impact of Covid-19 on income of middle-class salaried people. The main methodology used is primary sample survey of 105 respondents living in Mumbai and Navi Mumbai city.
\end{abstract}

Keywords: Covid-19, income, impact, lockdown, middle class.

\section{INTRODUCTION}

Mankind is dealing with a global health calamity COVID-19 pandemic. The corona virus came into light on December 2019, subsequently the virus spread in China and to the rest of the world. The countries with the greatest economies such as India, USA, UK, Germany, Russia, etc couldn't get away from the brunt of this deadly virus. The Indian government took a momentous step to initiate a lockdown in the entire country to handle the circumstances at the earliest without getting it out of its control and instructed all the private and public offices to close down their operations and instructed all employees to get back to their home. As the spread of virus expanded in India combined with the lockdown, Indian households experienced drastic changes with respect to many aspects in their lives

The covid-19 pandemic has created an economic calamity, shutting down businesses and jobs around the country thus affecting the standard of living of the middle class. Middle class is described as individuals and household who normally come between the upper class and lower class within a socioeconomic hierarchy.

Middle Class

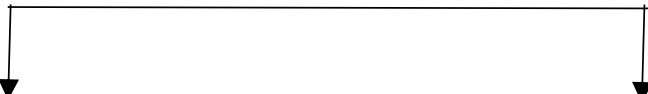

Lower Middle Class
Middle Class

\section{Upper Middle Class}

- $\quad$ Lower Middle Class: Annual income of a family earning between 50,000 and 4.5 Lakhs a year.

- $\quad$ Middle Class: An annual income of a family of four earning between 10 and 15 Lakhs.

- $\quad$ Upper Middle Class: An annual income of a family of four earning between 25 and 30 Lakhs. ( J Leo, S Srinivasan, C D Nanda Kumar vol12 issue 02,2021)

The average number of employed persons during March 2019- March 2020 were over 403 million (403,770,566). In April 2020, this number came down to roughly 282 million $(282,203,804)$, which is a drop in total employment of a little over 120 million, roughly 30 percent drop in the first month of the lockdown. In other words, employment in April 2020 was 70 percent of the employment in the preceding year. (Ashwini Deshpande2020)

\section{LITERATURE REVIEW}

Coronavirus is an illness with a very high mortality rate. It brought about a wide pandemic topography and around 210 nations and districts all over the world were impacted by its unendurable impacts. (Tushar kholia,2020). There are 24.9 million confirmed cases including 6.7 million existing cases of Covid-19 all over the world till now. The current status 
DOI: 10.17148/IARJSET.2021.8919

of such cases in India is 3.4 million confirmed cases including 0.7 million existing cases (Data Sources: Ministry of Health and Family Welfare, Government of India [MoHFW1], World Health Organisation [WHO2], 29 August 2020). It is very difficult to predict the current situation throughout the globe. This is definitely going to impact the economy adversely. The major factors are non-availability of vaccine, prolonged situations of lockdown, social distancing norms, containment, etc. (Gupta and Bansal,2020). Supply scarcities are anticipated to affect various sectors because of panic buying of people. There have been prevalent reports on scarcity of pharmaceuticals, through various sectors witnessing panic buying and as a result of its shortage in food and other essential grocery items have raised. (Dr. Smitha B Nair, Midhu Nair ,2020). Household financial transaction data was used to analyse the effect of the COVID-19 virus on household consumption in the United States. With the number of cases increasing, households have started changing their traditional expenditure dramatically in many major categories. Initially, the costs, particularly for the retail, credit card, and food products, increased sharply. Despite this, overall spending declined significantly. By 29 March in states where shelter orders were in force, households reacted more strongly. Greater social distance is correlated, in particular in restaurants and retail, with declines in spending (Neeraj Garg ,2020). Indian Prime Minister on his first address to nation on COVID-19 ( March 19) has put in a request to the high income segment community to take care of the financial requirements of those who render services to them directly or indirectly and further in another live telecast after few days fascinated not to deduct the salary of private employees, contractual employees, casual labours and outsourced employees as they could not turn up to their work place due to lockdown and they shall be considered as "on duty" during the tenure of lockdown. Hence ensured the non-interrupted payment of salary to households. (Dr. Smitha B Nair, Midhu Nair,2020)

\section{OBJECTIVES AND SCOPE OF THE STUDY}

The focus of the study is to evaluate the impact of Covid-19 pandemic on income of middle class in Mumbai and Navi Mumbai city. Scope of the research is to find the impact of Covid-19 pandemic on salaried people.

\section{RESEARCH METHODOLOGY}

Data collection is through secondary data and primary data. The secondary data is collected from various websites and published sources.

The study comprised of all middle class (18 years and above) residing in India. The survey targeted the population of all middle-class residents in Mumbai and Navi Mumbai, India.

To collect the relevant data for carrying out the research study a questionnaire was floated with several questions on various variables. The total responses received are 105 from Mumbai and Navi Mumbai

Demographics: Age, Qualification, Nature of Employment, income group, employment status, loss of employment, reduction in income, increase in income. The total responses received are 105 from Mumbai and Navi Mumbai

The survey was conducted for different employment sectors such as banking, insurance, teaching, information technology, hospitality, constructions, pharmaceutical, entertainment, hotel etc

\section{Endoyment Feed \\ tobiesphes}

\section{Emplomment Sitsis \\ 115 ingures}
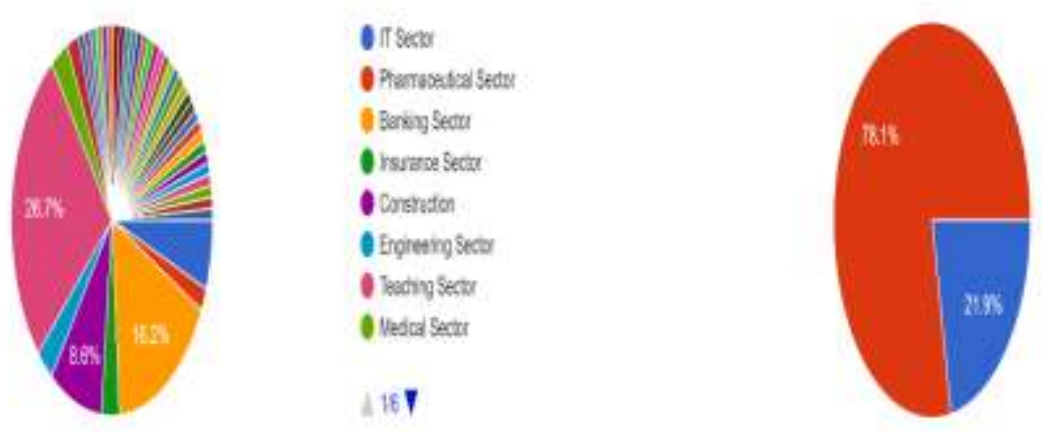

Oplatistar

Opirit Seatar

The combined sample data consist of employed (salaried) people indulged in private sector and public sector. According to the sample data collected people employed in private sector are $82(78.1 \%)$ and that of in public sector are $23(21.9 \%)$ 


\section{International Advanced Research Journal in Science, Engineering and Technology}

Vol. 8, Issue 9, September 2021

DOI: $10.17148 /$ IARJSET.2021.8919

\section{Nature of Employment}

195iesponos

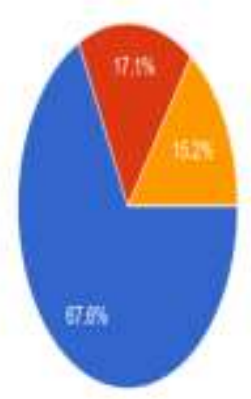

horme Group 0 Montity?

105 expriat

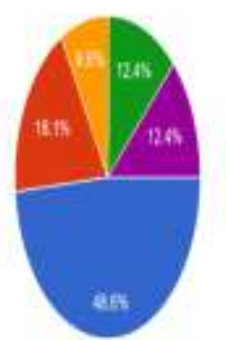

acressin

oscoriso

ensing

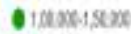

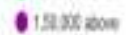

The data is stratified as employment nature. $67.6 \%$ respondents are permanent job, $17.1 \%$ are on temporary basis an $15.2 \%$ are on contract. The income groups classified in five categories ranging from Rs.30,000 to Rs.1,50,000.

\section{Loss of Emploment dring Covid:-s?}

165 enomith

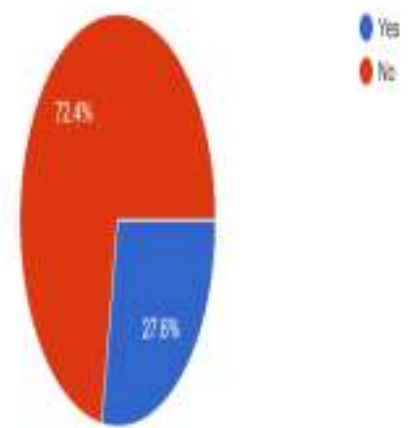

\section{Reduction in hcome dring Covid-19}

105isomes

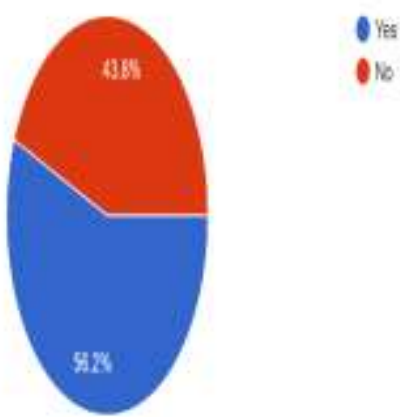

Out of 105, 29 respondents are lost their job and 59 respondents faced the reduction in the income

\section{FINDING AND OBSERVATION}

Covid-19 restrictions were put to control it had adverse effect on the income of the people to the great extent. It is observed that in public sector there no significant impact is seen, whereas the private sector is largely affected. In private sector employees are retrenched from the job and in some companies the pay scales also reduced In the age group of 21- to $30(40 \%), 31-40(21.7 \%) 41-50(37 \%)$ and 51-60 (41.6\%) loss of employment is observed, which is considered significant. Covid-19 pandemic has affected the employment in hotel industry, entertainment industry, IT and teaching sectors.

To find the impact of Covid-19 pandemic on income of middle-class the following hypothesis is framed

$\mathrm{H}_{0}$ - There is no relation between age and loss of employment

$\mathrm{H}_{1}-$ There is a relation between age and loss of employment 
International Advanced Research Journal in Science, Engineering and Technology

Vol. 8, Issue 9, September 2021

DOI: 10.17148/IARJSET.2021.8919

LOSS OF EMPLOYMENT

\begin{tabular}{|l|l|l|l|}
\hline AGE GROUP & YES & NO & TOTAL \\
\hline $21-30$ & 8 & 12 & 20 \\
\hline $31-40$ & 5 & 18 & 23 \\
\hline $41-50$ & 10 & 17 & 27 \\
\hline $51-60$ & 5 & 7 & 12 \\
\hline TOTAL & 28 & 54 & 82 \\
\hline
\end{tabular}

\begin{tabular}{|l|l|l|l|}
\cline { 2 - 4 } CHI- SQUARE TEST & $\begin{array}{l}\text { OBSERVED } \\
\text { VALUE }\end{array}$ & $\begin{array}{l}\text { EXPECTED } \\
\text { VALUES }\end{array}$ & $\begin{array}{l}\text { (Obs val-Exp val) } \\
\text { 2/Exp val }\end{array}$ \\
\cline { 2 - 4 } 8 & 7 & 0.14 \\
\hline 12 & 13 & 0.076 \\
\hline 5 & 8 & 0.69 \\
\hline 18 & 15 & 0.6 \\
\hline 10 & 9 & 0.1 \\
\hline 17 & 18 & 0.05 \\
\hline 5 & 4 & 0.25 \\
\hline 7 & 8 & 0.125 \\
\hline & & 2.031 \\
\hline
\end{tabular}

Significant value $=0.05$

Calculated value $=2.031$

Tabular value $=7.815$

$2.031<7.815$

Therefore, null hypothesis

is accepted

The Tabular value is more than calculated value. Thus, Null hypothesis is proved. It means the retrenchment is done irrespective of all age groups.

\section{QUALIFICATION AND LOSS OF EMPLOYMENT}

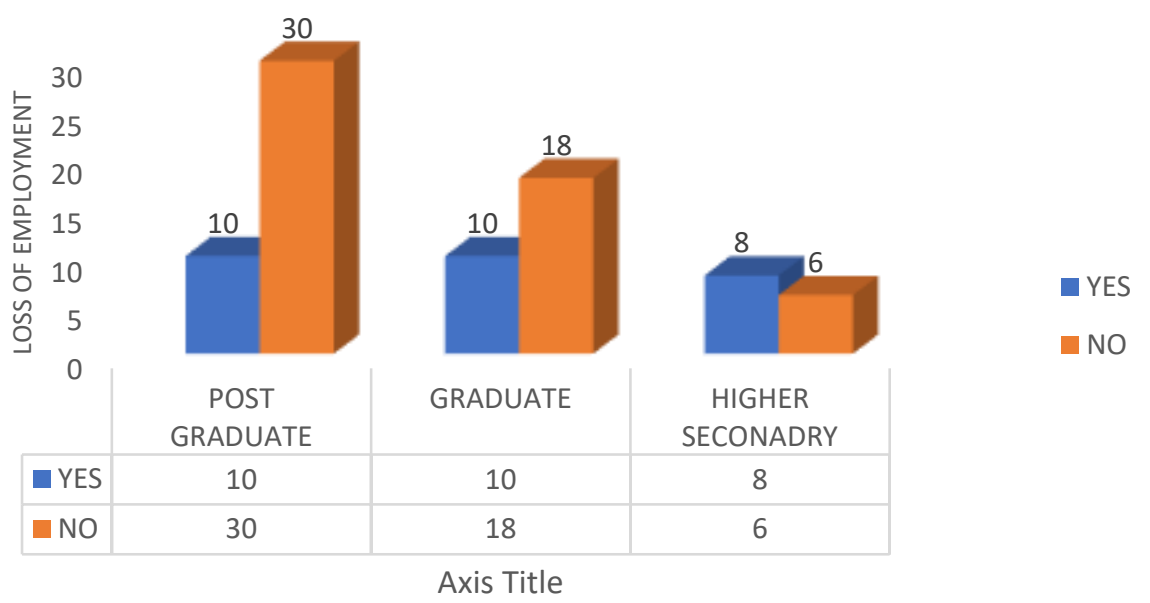

Here it also observed that retrenchment is done irrespective of the qualification. The chi- square test is conducted to find that there is no relation between qualification and loss of jobs. 
International Advanced Research Journal in Science, Engineering and Technology

Vol. 8, Issue 9, September 2021

DOI: $10.17148 /$ IARJSET.2021.8919

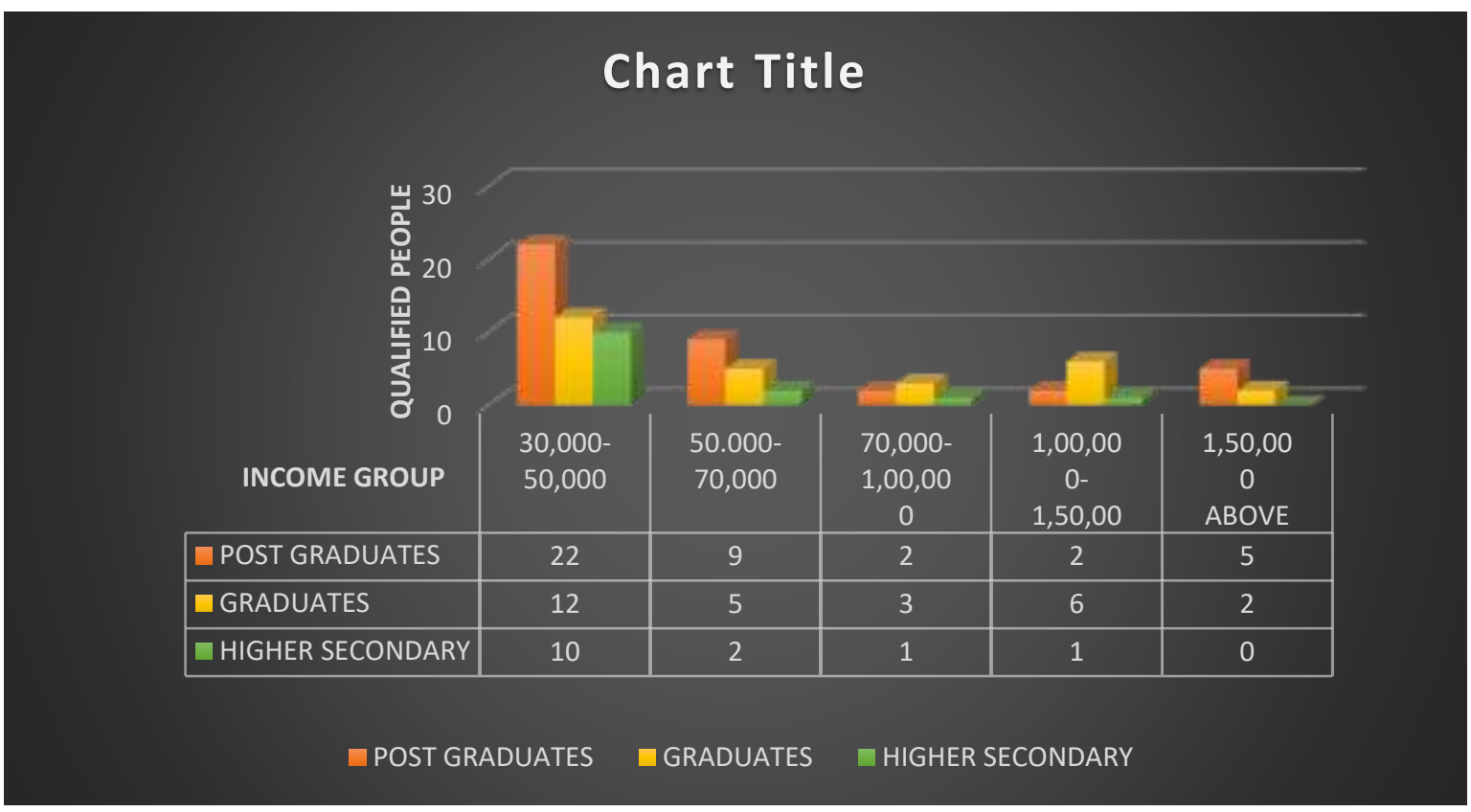

According to the survey done, it is observed that there are maximum number of people who belong to the income group of 30,000-50,000 per month.

To find the relation between qualification and loss of employment during the Covid-19 pandemic, chi-square test is conducted and the following hypothesis is framed

$\mathrm{H}_{0}-$ There is no relationship between age group and reduction in income.

$\mathrm{H}_{1}$ - There is relationship between age group and reduction in income.

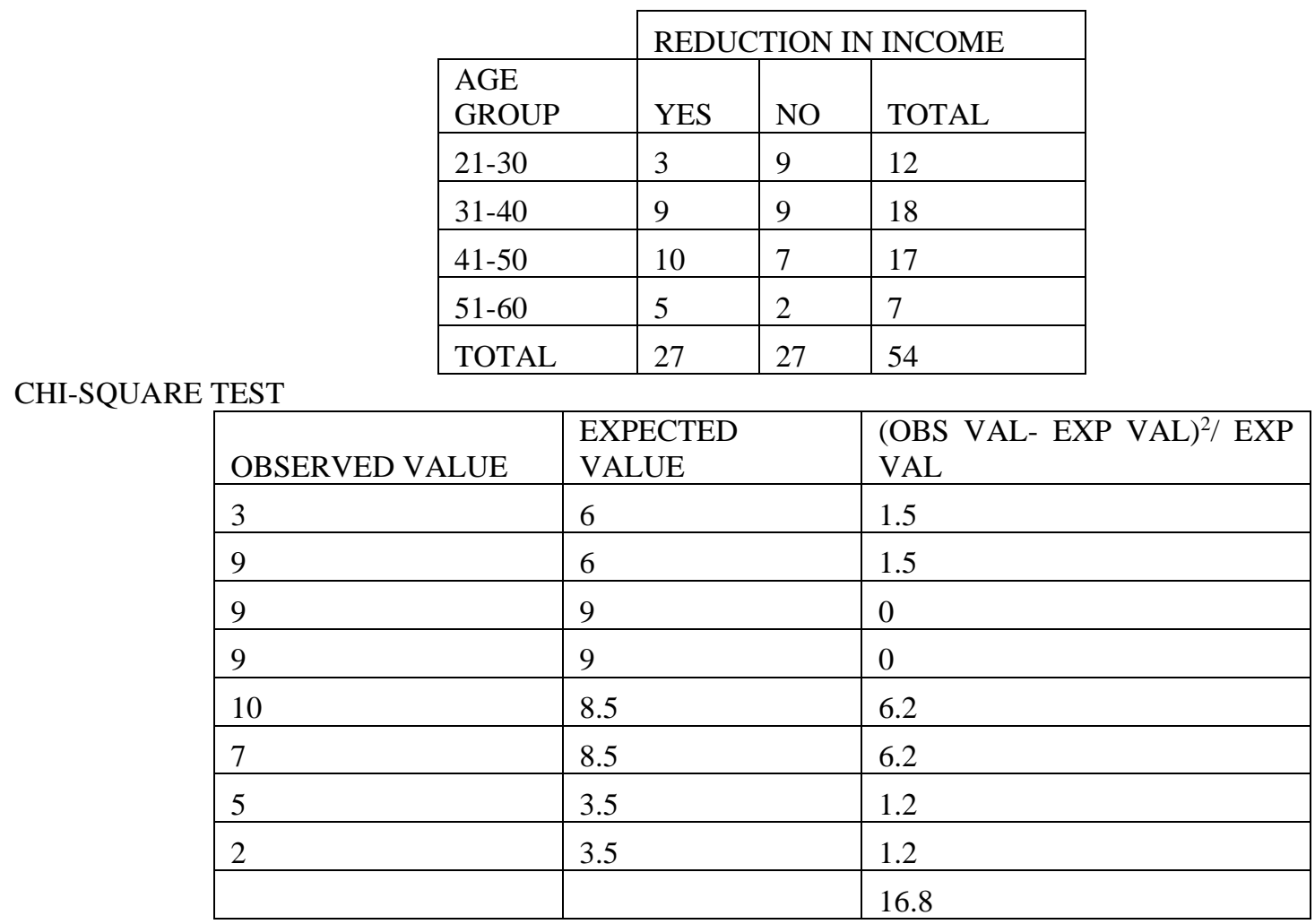




\section{International Advanced Research Journal in Science, Engineering and Technology}

Vol. 8, Issue 9, September 2021

DOI: 10.17148/IARJSET.2021.8919

Significant Value $=0.05$

Calculated Value $=16.8$

Tabular Value $=7.81$

$16.8>7.81$

Therefore, alternate hypothesis is accepted

Hence, we reject the null hypothesis and accept the alternate hypothesis. It shows that there is a relationship between age group and reduction in income.

To find the relation between qualification on reduction in income chi-square test was conducted and the following hypothesis was framed

$\mathrm{H}_{0}$ - There is no relationship between qualification and reduction in income

$\mathrm{H}_{1}$ - There is a relationship between qualification and reduction in income

\begin{tabular}{|c|c|c|c|}
\hline \multicolumn{4}{|c|}{ REDUCTION IN INCOME } \\
\hline QUALIFICATION & YES & NO & TOTAL \\
\hline POST GRADUATES & 23 & 17 & 40 \\
\hline GRADUATE & 14 & 14 & 28 \\
\hline HIGHER SECONDARY & 12 & 2 & 14 \\
\hline TOTAL & 54 & 28 & 82 \\
\hline
\end{tabular}

\begin{tabular}{|l|l|l|}
\hline $\begin{array}{l}\text { OBSERVED } \\
\text { VALUE }\end{array}$ & $\begin{array}{l}\text { EXPECTED } \\
\text { VALUE }\end{array}$ & $\begin{array}{l}\text { (Obs val-Exp } \\
\text { val }{ }^{2} \text { /Exp val }\end{array}$ \\
\hline 23 & 26 & 0.34 \\
\hline 17 & 14 & 0.64 \\
\hline 14 & 18 & 0.8 \\
\hline 14 & 10 & 1.6 \\
\hline 12 & 9 & 1 \\
\hline 2 & 5 & 1.8 \\
\hline & & $\mathbf{6 . 1 8}$ \\
\hline
\end{tabular}

Significant Value $=0.05$

Calculated Value $=6.18$

Tabular Value $=5.99$

$6.18>5.99$

Hence, we reject null hypothesis and accept Alternate hypothesis. It shows that less qualified people got less pay scale and salaries during Covid-19 pandemic. The reduction in income varies from $10 \%$ to $50 \%$. the reduction in income is found in the teaching sector, construction industry, IT sectors, banking sector, hotel industry, entertainment industry.

It also observed that in some cases there is no impact on income. In some cases, the income has increase $10 \%-20 \%$. some public sector there was increase in pay scale. 
DOI: $10.17148 /$ IARJSET.2021.8919

\section{CONCLUSION:}

the outbreak of Covid-19 pandemic the government took initiatives to control the spread of virus, lockdown was imposed in metropolitan cities and other states of the country. Metropolitan cities like Mumbai and Navi Mumbai had great impact due the complete lockdown, business operations were stuck in between and even discontinued which affected the employment ratio irrespective of any sector, no sector has been escape from the adverse impact of the pandemic.

Here we have observed that there no significant impact on public sectors. Whereas the private sectors had great impact. No one knows that how long the virus is going to exist in this world affecting the economy and growth of middle class. Definitely the situations are uncertain but to stabilise the situation and the standard of living of the middle class, online job opportunities should be made available and employers should try to get back their employees to the work and try to bring them to original pay scales as and when the pandemic situations get in control

\section{REFERENCES}

1. How Does Household Spending Respond to an Epidemic? Consumption during the 2020 COVID-19 Pandemic Scott R Baker, Robert A Farrokhnia, Steffen Meyer, Michaela Pagel, Constantine Yannelis

2. The Covid-19 Pandemic and Lockdown: First Order Effects on Gender Gaps in Employment and Domestic Time Use in India * Ashwini Deshpande $†$ July 17,2020

3. The effect of COVID-19 on Family Budget: Changes in Family Financial?* Tushar Kholia† October 2020

4. Covid-19 Disruption of Middle-Class Monthly Household Income and Budget Monika Gupta *, Shubhi Bansal2020

5. An Economic Impact Of Covid-19 In India ( J Leo1, S Srinivasan2, C D Nanda Kumar3) 2021

6. Impact on Earnings and Expenditure of Indian Households during Lockdown due to the outbreak of COVID-19. Neeraj Garg 2020

7. A Study on COVID-19 and its Impact on Indian Economy Dr. Smitha B Nair1, Midhu Nair Volume 9 Issue 7, July 2020

8. Pooja Dahiya; Roopsi Kaushik; Anil Sindhu. "Corona virus: an Overview Along with Its Alternative Diagnostic Measures". International Research Journal on Advanced Science Hub, 2, Special Issue ICARD 2020, 2020, 163-169. doi: 10.47392/irjash.2020.113 